\title{
Fresh and hardened properties of self-compacting repair mortar made with a new reduced carbon blended cement
}

\author{
AвoubaKeUR BOUKHELKHAL- Civil engineering laboratory, University of Amar Telidji, Algeria \\ BENCHAA BENABED - Civil engineering laboratory, University of Amar Telidji, Algeria \\ Érkezett: 2019. 07. 13. - Received: 13. 07. 2019. - https://doi.org/10.14382/epitoanyag-jsbcm.2019.19
}

\begin{abstract}
The present work investigates the effects of the use of waste brick as fine additive material (FAM) by partial replacement to the Ordinary Portland Cement (OPC) on the fresh and hardened properties of self-compacting repair mortar (SCRM) in order to produce a new reduced carbon blended cement. Waste brick which was available in a brick factory, was finely ground to obtain waste brick powder (WBP) before being incorporated in SCRM at substitution levels of 5\%, 15\% and $25 \%$. SCM was tested at fresh state with mini slump flow and mini V-funnel flow time. At hardened state, compressive and flexural strengths and ultrasonic pulse velocity (UPV) were measured. The results indicated that the particles size of WBP is coarser compared to the OPC. The use of WBP decreased the slump flow and increased in the same time the flow time. Including WBP in SCRM decreased not only the compressive and flexural strengths but also the UPV of SCM. WBP can be suitably used at replacement rate of 5 or $15 \%$ to produce a new reduced carbon blended cement. From environmental point of view, introducing WBP has a positive impact in decreasing the amount of $\mathrm{CO}_{2}$ released from cement plants into the atmosphere. Good correlations were found between strength and substitution levels of WBP.

Keywords: Self-compacting repair mortar, waste brick powder, substitution, blended, strength, environment

Kulcsszavak: öntömörödố javító habarcs, téglapor, helyettesítés, kevert, szilárdság, környezet
\end{abstract}

Aboubakeur BOUKHELKHAL PhD, Assistant professor at the Department of Civil Engineering, University of Laghouat, Algeria. His research interests include, self-compacting concrete and mortar, ordinary concrete, rheology, mechanical behavior and durability of concrete and mortar with Ordinary Portland Cement and mineral additions, effects of hot climate.

Benchaa BENABED PhD, Associate professor at the Department of Civil Engineering, University of Laghouat, Algeria. His research interests include, self-compacting concrete, reuse of local materials, rheology and durability of cement-based materials. *Corresponding author. E-mail: b.benchaa@ lagh-univ.dz

\section{Introduction}

Self-compacting mortar (SCM) is highly fluid mortar that can flow and fill all formwork under its own weight.

The self-compactability property allows using SCM as a repair material for reparation end rehabilitation of damaged reinforced concrete in congested area or with complicated shape. For ensuring the self-compactability of SCRM, two parameters must be taken into consideration: the use of superplasticizer (SP) and the incorporation cement and FAM with high volume [1]. As it known, SP reduces the water/cement ratio and provides more fluidity in the mixture and leads to higher compressive strength. The incorporation of FAM plays an important role in ensuring the resistance to segregation and bleeding. Without the use of FAM, self-compacting concrete (SCC) or mortar need a high content of OPC, and this can lead to many problems such as the increase in the cost production, the high consumption of energy and natural resources and high amount of $\mathrm{CO}_{2}$ emitted into the atmosphere.

As concrete is the most widely used building material with amount of 12 billion tons per year, which corresponds to a consumption of $1 \mathrm{~m}^{3} /$ person / year [2-3]. Its manufacture uses a binding material which is most often Portland cement. It is well known that the production of cement is very expensive in terms of economics, and polluting in terms of environment impacts. Moreover, the quantity of cement produced globally is growing remarkably, it was estimated at 3.6 trillion tons in 2011 and will rise to 5.8 trillion tons in 2050 , which will increase the
$\mathrm{CO}_{2}$ emissions from 3.24 trillion tons to 5.22 trillion tons $(1 \mathrm{~kg}$ of cement produced emits $0.9 \mathrm{~kg} \mathrm{CO}_{2}$ ) [4-5]. It is noted that the cement industry sector is responsible for $5 \%$ to $8 \%$ the global amount of $\mathrm{CO}_{2}$ emitted into the atmosphere [6]. The most effective solution is to reduce the amount of clinker produced by replacing it with FAM having similar properties to clinker. Blast furnace slag, fly ash, silica fume, natural pozzolana, limestone fillers are the additive materials most used in the cement industry. The use of FAM have shown a great interest in the latest years from the industrial and constrictor in reason of their technical, economical and environmental advantages impact. Pastes, mortars and concretes incorporating FAM showed better properties such as the low rate of hydration, low permeability, low consumption of Portland cement and lowimpact environmental materials related to the low emissions of $\mathrm{CO}_{2}$ [7-9]. Slag, fly ash, silica fume, limestone are the most used FAM in the world. Another source of FAM is the calcined clays such as metakaolin, brick powder or bentonite. It is known that these calcined clays were obtained by calcination or thermal treatment of kaolin, brick clay or bentonite, respectively [10-11]. Calcined clays are considered as pozzolanic materials and have a positive effect especially on mechanical and durability properties of concrete. FAM from agriculture waste such as rice husk ash (RHA) and sugarcane bagasse ash were successfully used in the production of SCC [12-14]. The characteristics of concretes and mortars are strongly influenced by the type, source, chemical, mineralogical, physical and mechanical properties of FAM [1520]. Many researches papers that studied the possible use of 
FAM to prepare mortar or concrete for rehabilitation and repair of reinforced concrete structures were published in the recent days [21-25]. Benabed et al. [21] were investigated the effect of limestone powder as a partial replacement of crushed quarry sand on properties of self-compacting repair mortars. They concluded that the use of limestone powder in repair mortar and concrete application would offer technical, economical and environmental advantages for concrete producers.

The main objective of this work is to investigate the effects of waste brick powder as substitute of the Ordinary Portland cement on the fresh and hardened properties of self-compacting repair mortar in order to produce a new reduced carbon blended cement. In this research work, waste brick powder was incorporated at substitution levels of 5, 15 and $25 \%$, keeping all the other ingredients and proportions constant. The mortar mixtures were tested at fresh state to evaluate the flowability, filling ability and the risk to bleeding or segregation. At hardened state, compressive and flexural strengths and ultrasonic pulse velocity were determined at ages of $1,3,7,28$ and 90 days.

\section{Materials and experimental tests}

\subsection{Materials}

According to the European Standards EN 197-1, Ordinary Portland Cement (OPC, CEMI 42.5) was used in all SCRM mixes. The waste brick powder, which is used as mineral admixture, was obtained from brick waste in a brick factory. The chemical composition and physical properties of the OPC and WBP are presented in Table 1. It was noted that WBP is mainly consisted of silica (65.93\%) with low percentage of alumina. Strength activity index showed that WBP has acceptable pozzolanic reactivity with strength activity index of 0.75 at 28 days.

In order to determine the particle size distribution of cement and WBP, laser distribution analysis was performed and the results are shown in Fig. 1. The results indicated that the WBP has a continuous particle size distribution as the OPC. Table 1 gives the diameter of particles corresponding to 10,50 and $90 \%$ of passing. It can be observed from this table that about of $50 \%$ of WBP particles have a size lower than $44.32 \mu \mathrm{m}$, contrary to the cement in which $50 \%$ of particles have a size lower than $12.35 \mu \mathrm{m}$. These results demonstrates that WBP is coarser than the OPC.

Fig. 2 shows the results of SEM of WBP. This test gives a great idea about the particle shape of the material tested and confirms the obtained results for particles size distribution (Fig. 1). Scanning electron microscope (SEM) exam was also performed on OPC and WBP and it is presented in Fig. 2. It can be concluded from Fig. 2 that WBP has coarser and more angular particles shape compared to OPC.

As fine aggregate, river sand was used with a maximum size of $5 \mathrm{~mm}$, density of 2.6 , coefficient of absorption of $0.59 \%$ and water content of $0.03 \%$. The chemical admixture used to produce various mixtures, is a polycarboxylates based highrange water reducers superplasticizer (SP). It has a specific gravity and $\mathrm{pH}$ of $1.07 \mathrm{~g} / \mathrm{cm}^{3}$ and 8 respectively.

\begin{tabular}{|c|c|c|c|}
\hline \multicolumn{2}{|c|}{ Component } & OPC & WBP \\
\hline \multicolumn{2}{|l|}{$\mathrm{SiO}_{2}(\%)$} & 18.83 & 65.93 \\
\hline \multicolumn{2}{|l|}{$\mathrm{CaO}(\%)$} & 61.54 & 6.78 \\
\hline \multicolumn{2}{|l|}{ MgO (\%) } & 1.27 & 2.25 \\
\hline \multicolumn{2}{|l|}{$\mathrm{Al}_{2} \mathrm{O}_{3}(\%)$} & 4.20 & 14.60 \\
\hline \multicolumn{2}{|l|}{$\mathrm{Fe}_{2} \mathrm{O}_{3}(\%)$} & 5.31 & 5.24 \\
\hline \multicolumn{2}{|l|}{$\mathrm{SO}_{3}(\%)$} & 1.96 & 0.05 \\
\hline \multicolumn{2}{|l|}{$\mathrm{K}_{2} \mathrm{O}(\%)$} & 0.49 & 3.13 \\
\hline \multicolumn{2}{|l|}{$\mathrm{T}_{1} \mathrm{O}_{2}(\%)$} & 0.20 & 0.74 \\
\hline \multicolumn{2}{|l|}{$\mathrm{Na}_{2} \mathrm{O}(\%)$} & 0.21 & 0.14 \\
\hline \multicolumn{2}{|l|}{$\mathrm{P}_{2} \mathrm{O}_{5}(\%)$} & 0.29 & 0.13 \\
\hline \multicolumn{2}{|c|}{ Loss on ignition (\%) } & 5.70 & 1.02 \\
\hline \multicolumn{2}{|l|}{ Specific density } & 3.11 & 2.54 \\
\hline \multicolumn{2}{|l|}{ Activity index $\mathbf{i}_{28}$} & - & 0.75 \\
\hline \multirow{4}{*}{$\begin{array}{l}\text { Finesses } \\
\text { characteristics }\end{array}$} & Finesses & 3300 & 2925 \\
\hline & $\mathrm{d}_{10}(\mu \mathrm{m})$ & 1.19 & 3.17 \\
\hline & $\mathrm{d}_{50}(\mu \mathrm{m})$ & 12.35 & 44.32 \\
\hline & $d_{90}(\mu \mathrm{m})$ & 40.53 & 100 \\
\hline
\end{tabular}

Table 1 Chemical composition and physical properties of OPC and WBP 1. táblázat OPC és WBP kémiai összetétele és fizikai tulajdonságai

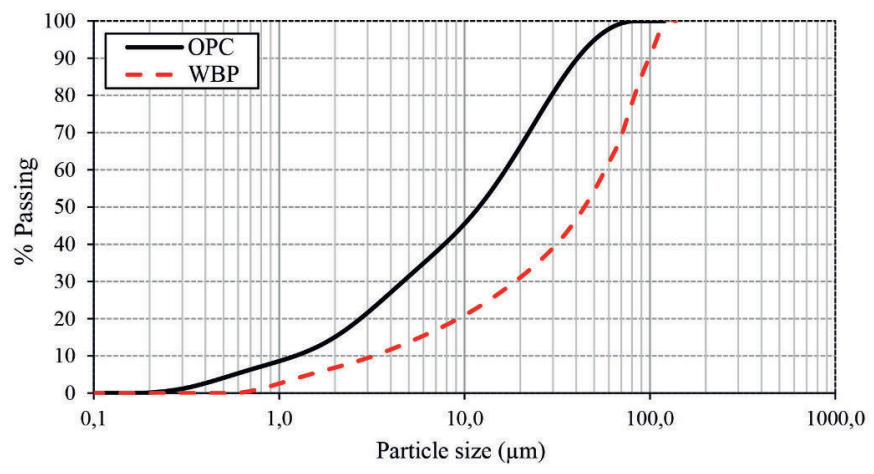

Fig. 1 Particle size distribution of OPC and WBP

1. ábra OPC és WBP szemmegoszlás diagrammja

\subsection{Mix proportion design}

Four mixtures were prepared to study the effect of the WBP on the fresh and hardened properties of SCM. WBP was included at substitution levels of 0, 5, 15 and 25\%. In all SCM mixtures, the amount of binder (OPC+WBP), water to binder (W/B) ratio and dosage of SP were kept equal to $692.65 \mathrm{~kg}, 0.4$ and $0.8 \%$, respectively. The mix proportions of SCM are given in Table 2.

\begin{tabular}{|c|c|c|c|c|c|c|c|c|}
\hline \multirow[b]{2}{*}{$\begin{array}{l}\text { Mix- } \\
\text { tures }\end{array}$} & \multirow[b]{2}{*}{ W/B } & \multicolumn{7}{|c|}{ Constituents } \\
\hline & & $\begin{array}{c}\text { OPC } \\
\left(\mathrm{kg} / \mathrm{m}^{3}\right)\end{array}$ & $\begin{array}{c}\text { WBP } \\
(\%)\end{array}$ & $\begin{array}{c}\text { WBP } \\
(\mathrm{kg} / \\
\left.\mathrm{m}^{3}\right)\end{array}$ & $\begin{array}{l}\text { Sand } \\
(\mathrm{kg} / \\
\left.\mathrm{m}^{3}\right)\end{array}$ & $\begin{array}{c}\text { Water } \\
(\mathrm{kg} / \\
\text { m³) }^{3}\end{array}$ & $\begin{array}{l}\text { SP } \\
(\%)\end{array}$ & $\begin{array}{l}\text { SP } \\
(\mathbf{k g} / \\
\left.\mathrm{m}^{3}\right)\end{array}$ \\
\hline OWBP & \multirow{4}{*}{0.4} & 692.65 & 0 & - & 1300 & 278.89 & 0.80 & 5.54 \\
\hline 5WBP & & 658.02 & 5 & 34.63 & & & & \\
\hline 15WBP & & 588.75 & 15 & 103.90 & & & & \\
\hline 25WBP & & 519.59 & 25 & 173.16 & & & & \\
\hline
\end{tabular}

Table 2 Mix proportions of SCM

2. táblázat Azalkalmazott betonreceptúrák 


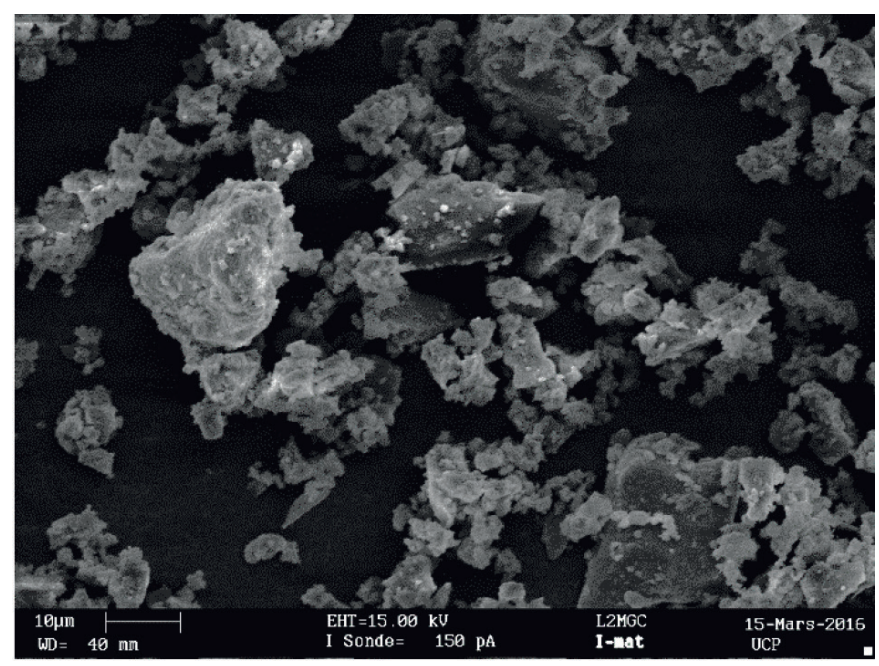

(a)

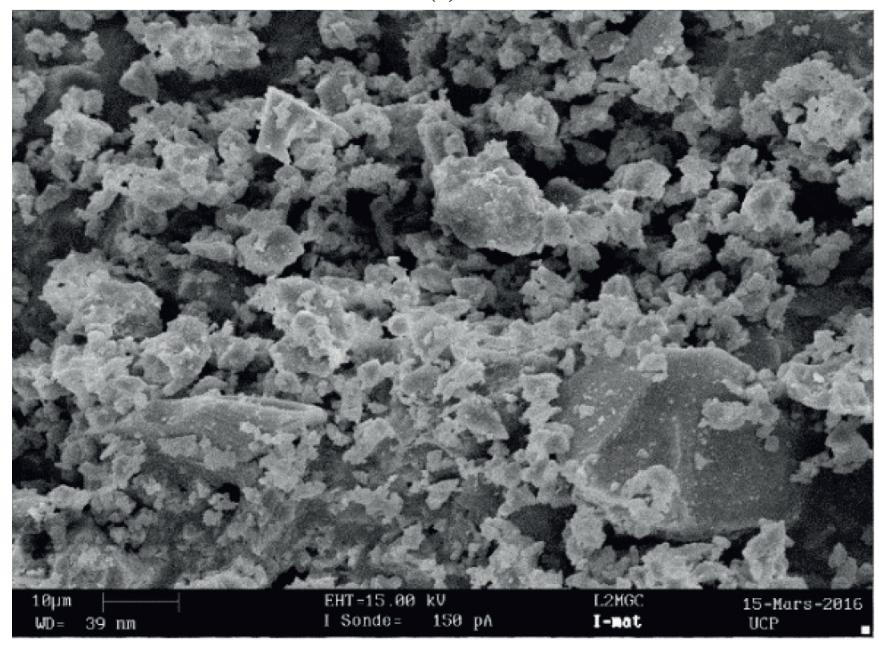

(b)

Fig. 2 SEM of: (a) OPC and (b) WBP

2. ábra OPC (a) és WBP (b) pásztázó elektronmikroszkópos felvételen

\subsection{Test procedure}

\subsubsection{Fresh mortar}

The mini slump flow and mini v-funnel tests were conducted to characterize the flowability, filling ability and stability of fresh mortar. In the mini slump flow (Fig. 3.a), a truncated cone mold was filled with mortar and lifted upwards. The final diameter of the mortar through two perpendicular directions was measured and the mean is calculated. Slump flow ranging between 27.5 and $33.5 \mathrm{~cm}$ are suggested to obtain a slump flow of $55-85 \mathrm{~cm}$ for SCC [26-27]. The flow time T25 is the time to reach a circle of diameter of $25 \mathrm{~cm}$ corresponding to the flow time T50 measured in SCC was also determined [28]. It can be noted that it is possible to evaluate the trend to segregation or bleeding of SCM through visual control. The mini v-funnel was filled completely with mortar and the bottom outlet is opened allowing to the mortar to flow out (Fig. 3.b). The v-funnel flow time Tv which is the elapsed time (s) between the opening of the bottom outlet and the time when the light becomes visible from the top was measured [29].

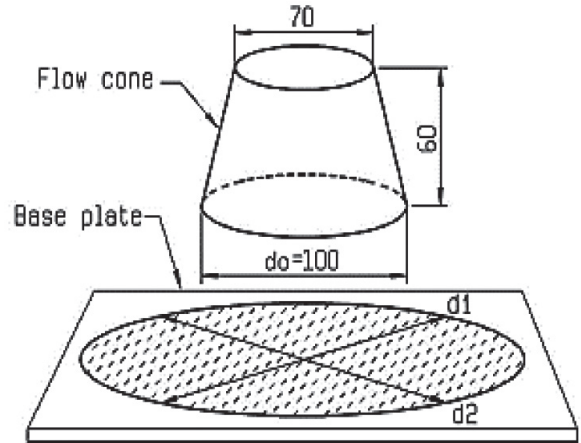

(a)

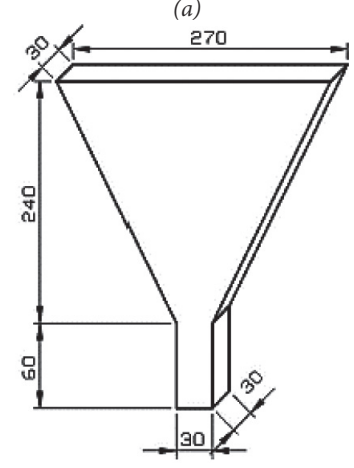

(b)

Dimensions in $\mathrm{mm}$

Fig. 3 Self-compacting mortar tests, (a) schematization of the mini-slump flow test (b) mini V-funnel test

3. ábra öntömörödő habarcs vizsgálat, (a) mini-roskadásvizsgálat sematikus ábrája, (b) mini $V$-tölcséres vizsgálat

\subsubsection{Hardened mortar}

From each mortar mixture, prismatic specimens of $40 \times 40 \times 160 \mathrm{~mm}$ in size were cast. After casting, all specimens were covered with plastic sheets for 24 hours, before they unmolded and transferred to conservation in conditioned room at $20 \pm 2{ }^{\circ} \mathrm{C}$ and $100 \%$ relative humidity until the time of test. For each mix, three specimens were used to determine flexural strength and pulse velocity values and six specimens to measure compressive strength at 1, 3, 7, 28 and 90 days. All these measures were carried out following European Standard EN 196-3 [30] and ASTM C597-97 [31].

\section{Results and discussion}

\subsection{Fresh mortar properties}

The results of slump flow and flow time $\mathrm{T}_{25}$ of mortar mixtures with and without WBP are illustrated in Fig. 4. The values of slump flow varied between 29.3 and $31.4 \mathrm{~cm}$. The use of WBP at replacement rate of $5 \%$ increases the slump flow, whereas a replacement rate of $15 \%$ slightly decreases the slump flow, but a replacement rate of $25 \%$ decreases significantly the slump flow. In contrary, increasing the amount of WBP until 5\% slightly reduces the flow time $\mathrm{T}_{25}$, but replacements rate of $15 \%$ or $25 \%$ increases the flow time $\mathrm{T}_{25}$. For mixtures including $5 \%$ of WBP, the quantity of WBP are very low and it is completely coated by the cement particles. However, the effect of WBP is more pronounced in SCM mixtures having $15 \%$ and $25 \%$ of WBP since the quantity substituted is higher. In addition, the angular shape and coarse particles of WBP are assumed to 
reduce the flowability of SCM leading to lower values of slump flow. It should be noted that, all SCM mixtures were visually examined and no risk to bleeding or segregation was observed.

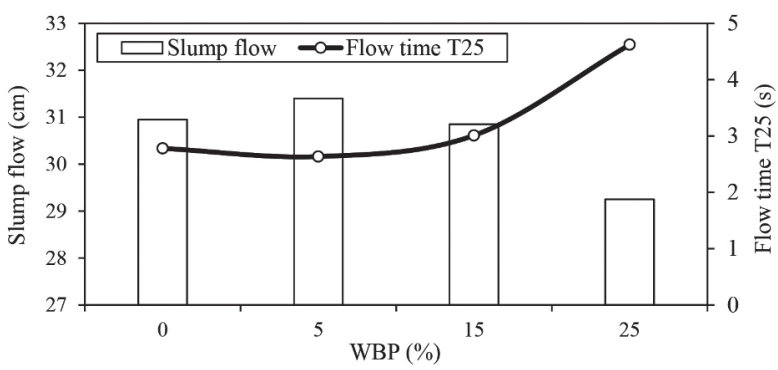

Fig. 4 Slump flow and flow time $T_{25}$ of mortar mixtures with percentage of WBP 4. ábra Roskadásos terülés és folyási idő $\left(T_{25}\right)$ a WBP mennyiség függvényében

Fig. 5 depicts the evolution of flow time Tv for all mortar mixtures. The $\mathrm{v}$-funnel flow time increases with increasing the percentage of WBP. The values of $\mathrm{v}$-funnel flow time ranged from 3.8 to $5.2 \mathrm{~s}$, these values are in the range recommended by EFNARC 2-10 s [29]. Incorporation of WBP at 5, 15 and 25\% increases the $\mathrm{v}$-funnel flow time by 9,13 and $38 \%$, respectively. Generally, the mortar viscosity is expressed by the T25 or Tv flow time. This means that the use of WBP increases the viscosity of SCM which is attributed to the angular shape and to the coarse particles of WBP which increase the resistance to the flow and consequently the viscosity of SCM.

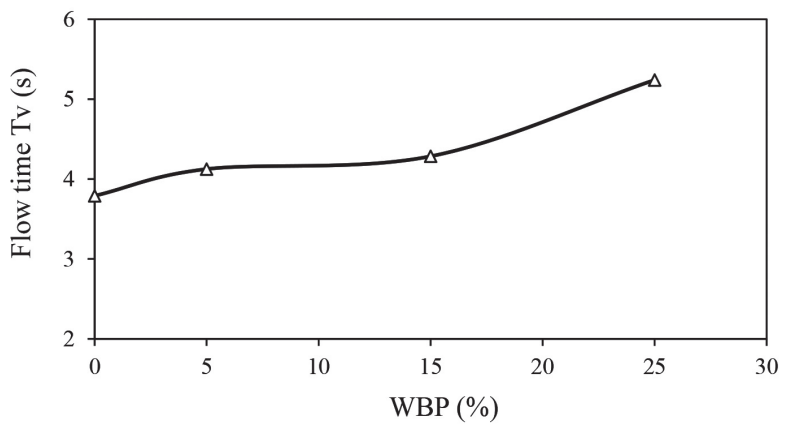

Fig. 5 Flow time $T_{v}$ of mortar mixtures with percentage of WBP

5. ábra Folyási idő (Tv) a WBP mennyiség függvényében

\subsection{Hardened mortar properties}

Fig. 6 presents the values of the compressive strength for mortar mixtures with plain cement and WBP. It was observed that the compressive strength of all SCM mixtures increases with increase in age of curing which attributes to the continuous of the hydration. SCM with plain cement presented the highest values of compressive strength at all age of curing, exception for 3 days of curing in which mixtures contained 5\% of WBP shown the higher compressive strength. Introduction of the WBP in SCM mixtures slightly decreased the compressive strength for substitution rate of 5 or $15 \%$ but considerably for substitution rate of $25 \%$. The decrease in the compressive strength of $5 \mathrm{WBP}, 15 \mathrm{WBP}$ and $25 \mathrm{WBP}$ mixes at 28 days is about $6.3,10.6$ and $35.3 \%$, and about $9.8,13.6$ and $38.6 \%$. This means that there is no strength gain in mixtures containing WBP after 28 days. WBP is considered as pozzolanic material but it is coarse than the cement which meaning that its fineness is low, so the pozzolanic activity did not take place at 90 days since the fineness played an important role in the pozzolanic activity [32].

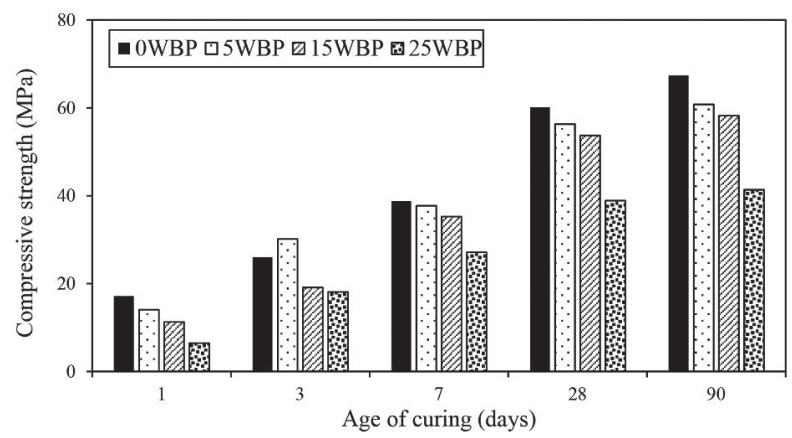

Fig. 6 Compressive strength of mortar mixtures with percentage of WBP 6. ábra Nyomószilárdság a WBP mennyiség függvényében

The values of UPV of all mortar mixtures are shown in Fig. 7. UPV is a non-destructive test that allows assessing the internal structure of the mortar or concrete without damaging the tested element. UPV increases with increase in the age of curing. The use of WBP in SCM mixtures caused a decrease in the UPV. The UPV of mixtures containing 5 or $15 \%$ of WBP are slightly inferior to those of control mixture, but mixtures with $25 \%$ of WBP show a high reduction in the UPV. Similar results were reported by Şahmaran et al. [32].

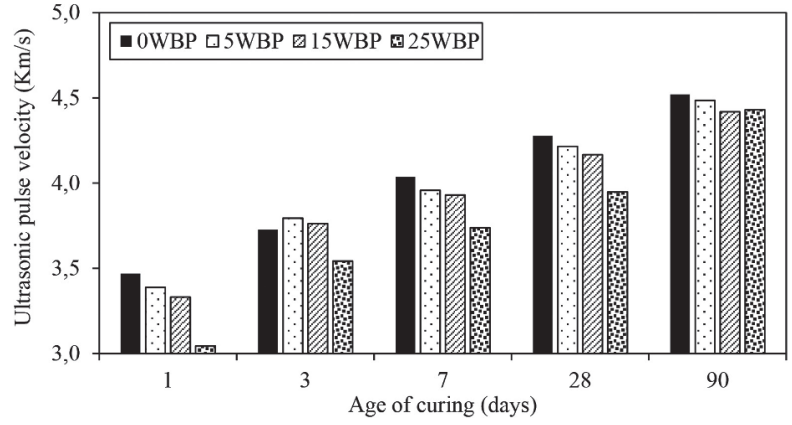

Fig. 7 Ultrasonic pulse velocity of mortar mixtures with percentage of WBP 7. ábra Ultrahangos impulzus sebesség a WBP mennyiség függvényében

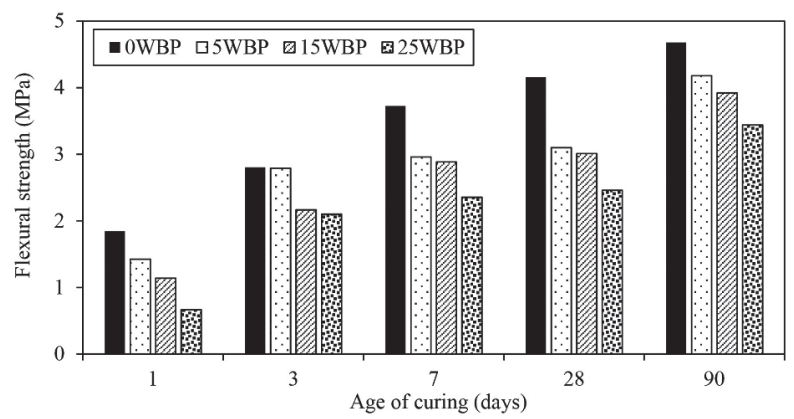

Fig. 8 Flexural strength of mortar mixtures with percentage of WBP 8. ábra Hajlitó szilárdság a WBP mennyiség függvényében

In Fig. 8, the flexural strengths of mortar mixtures with plain cement and WBP are plotted as a function of the age of curing. Due to continued hydration, it was observed that the flexural strength increases with an increase in the age of curing. Compared to the mixture with plain cement, it appears that the introduction of WBP decreases the flexural strength and as the amount of WBP increased the flexural strength decreased. 


\subsection{Environmental benefit of WBP blended cement}

Cement industry is one the most source of $\mathrm{CO}_{2}$ emission in civil engineering field. The production of $1 \mathrm{~kg}$ of cement releases into the atmosphere about $0.9 \mathrm{~kg}$ of $\mathrm{CO}_{2}$. Fig. 9 shows the quantity of $\mathrm{CO}_{2}$ emission related to the binder for all SCRM mixtures. The results have shown a reduction in the amount of $\mathrm{CO}_{2}$ when cement is replaced by waste brick powder. Using replacement level of WBP of 5\%,15\% and $25 \%$ reduces the $\mathrm{CO}_{2}$ emission to $401.85,359.55$ and $317.25 \mathrm{~kg}$, respectively. In recent study, Kavitha et al. [33] have reported that replacing cement by metakaolin with rates ranging from $5 \%$ to $15 \%$ decreased the $\mathrm{CO}_{2}$ emission by $4 \%$ to $11 \%$.

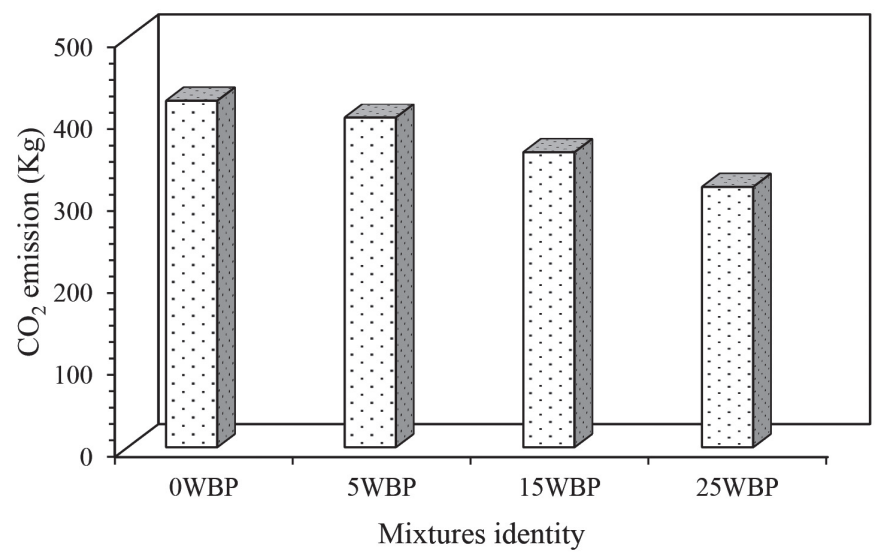

Fig. 9 Environmental impacts of mixtures with percentage of WBP

9. ábra Különböző WBP adagolású keverékek környezeti hatása

\subsection{Correlation between mechanical properties and substitution levels of WBP}

In order to understand the relationship between mechanical properties (compressive strength $f_{c}$, flexural strength $f_{f}$ ) and the percentage of waste brick powder, correlations were realized between them and the results are shown in Figs. 10 and 11, and Table 3. It was noted from the obtained results that the polynomial correlation between mechanical properties and the substitution level of waste brick powder for different age of curing was found good to excellent with very acceptable coefficient of regression. It should be noted that other correlations were also explored, but obtained results showed that these correlations are not strong compared to the used correlation.

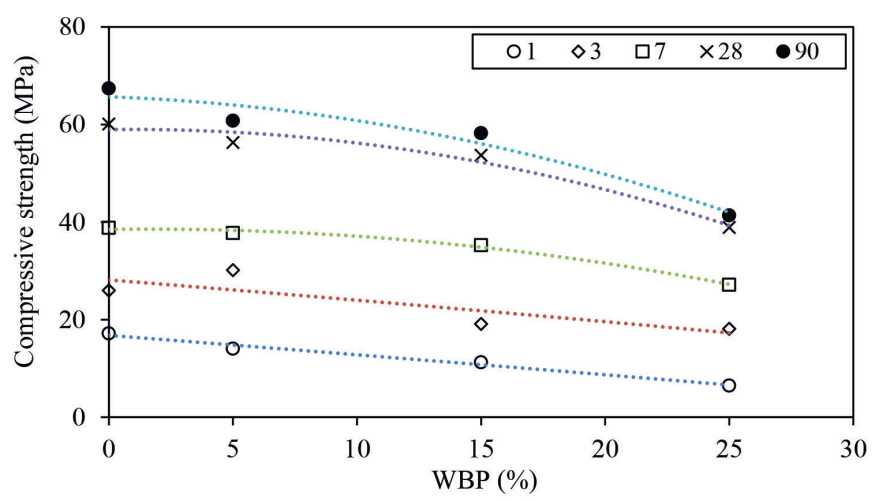

Fig. 10 Correlation between compressive strength and percentage of WBP at different ages 10. ábra Nyomószilárdság és WBP mennyiség összefüggése különbözö korú keverékek esetén

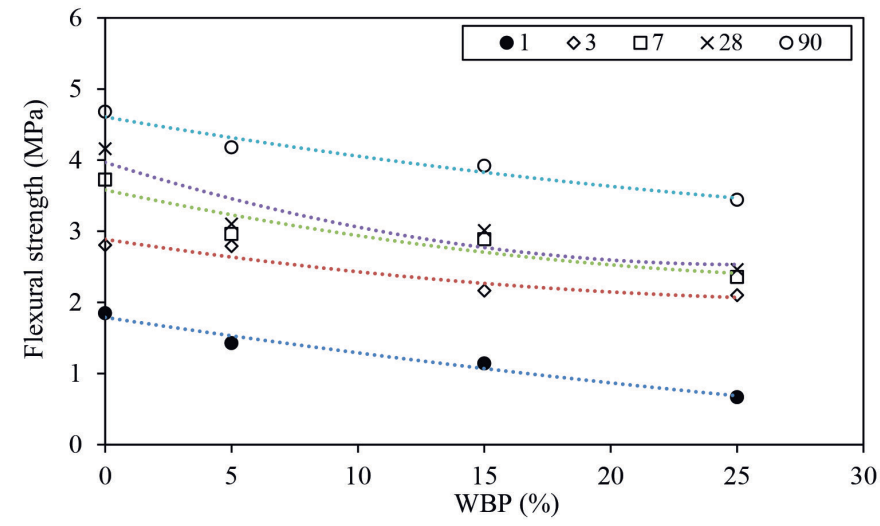

Fig. 11 Correlation between flexural strength and percentage of WBP at different ages 11. ábra Hajlitó szilárdság és WBP mennyiség összefüggése különböző korú keverékek esetén

$\begin{array}{cccc}\text { Age } & \begin{array}{c}\text { Correlation between } \mathrm{f}_{\mathrm{c}} \text { and } \\ \text { percentage of WBP }\end{array} & \begin{array}{c}\text { Correlation between } \mathrm{f}_{\mathrm{f}} \text { and } \\ \text { percentage of WBP }\end{array} \\ \text { Regression equation } & \mathbf{R}^{2} & \text { Regression equation } & \mathbf{R}^{2}\end{array}$

$1 y=-0.0005 x^{2}-0.3937 x+16.7890 .98 \quad y=0.0004 x^{2}-0.0537 x+1.78890 .98$

$3 y=-0.0012 x^{2}-0.4032 x+28.147 \quad 0.91 y=0.0009 x^{2}-0.0542 x+2.8866 \quad 0.90$

$7 \quad y=-0.0207 x^{2}+0.0671 x+38.5 \quad 0.96 \quad y=0.0012 x^{2}-0.0757 x+3.5806 \quad 0.86$

$28 y=-0.034 x^{2}+0.0641 x+58.962 \quad 0.96 \quad y=0.0022 x^{2}-0.1134 x+3.969 \quad 0.95$

$90 y=-0.0306 x^{2}-0.1808 x+65.676 \quad 0.94 y=0.0006 x^{2}-0.0613 x+4.6069 \quad 0.96$

Table 3 Regression equations and coefficients for different ages

3. táblázat Regressziós összefüggések és koefficienseik különböző korú minták esetén

\section{Conclusions}

Based on the experimental results and the analysis performed, the following conclusions can be drawn:

- SEM analysis indicated that the particles size of waste brick powder are coarser compared to the cement.

- At fresh state, self-compacting repair mortars with waste brick powder have shown low fluidity and high viscosity. But, values of slump flow and flow time are acceptable by the recommendations of self-compacting mortars production.

- The use of waste brick powder with a fineness lower than the cement resulted in a decrease in the compressive, flexural strength and the ultrasonic pulse velocity.

- WBP can be suitably used at replacement rate of 5 or $15 \%$ to produce a new reduced carbon blended cement.

- Adding WBP could be positive from the environment point of view because of its availability as a local waste. This means also that WBP is an interesting alternative material to produce eco-friendly self-compacting mortar.

- Several correlations between hardened properties (compressive and flexural strength) and the percentage of waste brick powder were explored. These results show that there is a good polynomial correlation between the studied properties compared to other correlations. 


\section{References}

[1] Benchaa, BENABED. (2018): Effect of combined use of crushed sand and Algerian desert dune sand on fresh properties and strength of self-compacting concrete. Epitoanyag-Journal of Silicate Based and Composite Materials, 70(5): 155-167, 2018. https://doi.org/10.14382/epitoanyag-jsbcm.2018.29

[2] Prabhu, G.G. - Hyun, J.H. - Kim, Y.Y. (2014): Effects of foundry sand as a fine aggregate in concrete production. Construction and Building Materials, 70: 514-521, 2014. https://doi.org/10.1016/j.conbuildmat.2014.07.070

[3] Siddique, R. - Aggarwal, Y. - Aggarwal, P. - Kadri, E.H. - Bennacer, R. (2011): Strength, durability, and microstructural properties of concrete made with used-foundry sand (UFS). Construction and Building Materials, 25: 1916-1925, 2011. https://doi.org/10.1016/j.conbuildmat.2010.11.065

[4] Cembureau. (2011). The European Cement Association Activity Report, 2011

[5] Scrivener, K. (2012): Issues in sustainability in cements and concrete. American Ceramic Society Bulletin, 91: 47-50, 2012.

[6] Najim, K.B. - Al-Jumaily, I. - Atea, A.M. (2016): Characterization of sustainable high performance selfcompacting concrete produced using $\mathrm{CKD}$ as a cement replacement material. Construction and Building Materials, 103: 123-129, 2016. https://doi.org/10.1016/j.conbuildmat.2015.11.037

[7] Uysal, M. - Sumer, M. (2011): Performance of selfcompacting concrete containing different mineral admixtures. Construction and Building Materials, 25:4112-4120, 2011. https://doi.org/10.1016/ j.conbuildmat.2011.04.032.

[8] Boukhelkhal, A. - Azzouz, L. - Belaïdi, ASE. - Benabed, B. (2016): Effects of marble powder as a partial replacement of cement on some engineering properties of self-compacting concrete. Journal of Adhesion Science and Technology, 30(22):2405-2419, 2016. http://dx.doi.org/10.1080/01694243.2016.1184402.

[9] Boukendakdji, O. - Kadri, E.H. - Kenai, S. (2012): Effects of granulated blast furnace slag and superplastizer type on the fresh properties and compressive strength of self-compacting concrete. Cement and Concrete Composite, 34(14):583-590, 2012. https://doi.org/10.1016/j.cemconcomp.2011.08.013.

[10] Singh Gill, A. - Siddique, R. (2018): Durability properties of selfcompacting concrete incorporating metakaolin and rice husk ash. Construction and Building Materials, 176:323-332, 2018. https://doi.org/10.1016/ j.conbuildmat.2018.05.054.

[11] Memon, S.A. - Arsalan, R. - Tommy, S.K. - Lo, Y. (2012): Utilization of Pakistani bentonite as partial replacement of cement in concrete. Construction and Building Materials, 30:237-242, 2012. https://doi.org/10.1016/ j.conbuildmat.2011.11.021.

[12] Memon, S.A. - Shaikh, M.A. - Akbar, H. (2011): Utilization of Rice Husk Ash as viscosity modifying agent in Self Compacting Concrete. Construction and Building Materials, 25:1044-1048, 2011. https://doi:10.1016/ j.conbuildmat.2010.06.074.

[13] Thanh, L.H. - Ludwig, H.M. (2016): Effect of rice husk ash and other mineral admixtures on properties of self-compacting high performance concrete. Materials and Design, 89:156-66, 2016. http://dx.doi.org/10.1016/ j.matdes.2015.09.120.

[14] Moretti, J.P. - Nunes, S. - Sales, A. (2018): Self-compacting concrete incorporating sugarcane bagasse ash. Construction and Building Materials, 172:635-649, 2018. https://doi.org/10.1016/j.conbuildmat.2018.03.277.

[15] Boukhelkhal, A. - Azzouz, L. - Benabed, B. - Belaïdi, A.S.E. (2017): Strength and durability of low-impact environmental self-compacting concrete incorporating waste marble powder. Journal of Building Materials and Structures, 4:31-41, 2017. https://doi.org/10.5281/zenodo.1134146.

[16] Boukhelkhal A. Comportement physico-mécanique et durabilité en climat chaud des mortiers autoplaçants à base d'ajouts binaires et ternaires. $\mathrm{PhD}$ thesis, University of Laghouat, Algeria, 2019, pp. 270. (In French)

[17] Ardalan, R.B. - Joshaghani, A. - Hooton, R.D. (2017): Workability retention and compressive strength of self-compacting concrete incorporating pumice powder and silica fume. Construction and Building Materials, 134: 116-122, 2017. https://doi.org/10.1016/j.conbuildmat.2016.12.090.
[18] Dobiszewska, M. - Schindler, A.K. - Pichór, W. (2018): Mechanical properties and interfacial transition zone microstructure of concrete with waste basalt powder addition. Construction and Building Materials, 177: 222-229, 2018. https://doi.org/10.1016/j.conbuildmat.2018.05.133.

[19] Lasseuguette, E. - Burns, S. - Simmons, D. - Francis, E. - Huang Y. (2019): Chemical, microstructural and mechanical properties of ceramic waste blended cementitious systems. Journal of Cleaner Production, 211: 12281238, 2019. https://doi.org/10.1016/j.jclepro.2018.11.240

[20] Boukhelkhal, A. - Azzouz, L. - Kenai, S. - Kadri, E.H. - Benabed, B. (2019): Combined effects of mineral additions and curing conditions on strength and durability of self-compacting mortars exposed to aggressive solutions in the natural hot-dry climate in North African desert region. Construction and Building Materials, 197: 307-318, 2019. https://doi.org/10.1016/j.conbuildmat.2018.11.233.

[21] Benabed, B. - Soualhi, H. - Belaidi, ASE. - Azzouz, L. - Kadri, E. Kenai, S. (2016): Effect of limestone powder as a partial replacement of crushed quarry sand on properties of self-compacting repair mortars. Journal of Building Materials and Structures, 3:15-30, 2016. https://doi.org/10.5281/zenodo.242480.

[22] Benyahia, A. - Ghrici, M. (2018): Behaviour of self-compacting repair mortars based on natural pozzolana in hot climate. Advances in Concrete Construction, 6(3):285-296, 2018. https://doi.org/10.12989/acc.2018.6.3.285.

[23] Felekoğlu, B. - Tosun, K. - Baradan, B. - Altun, A. - Uyulgan B. (2006): The effect of fly ash and limestone fillers on the viscosity and compressive strength of self-compacting repair mortars. Cement and Concrete Research, 36:1719-1726, 2006. https://doi.org/10.1016/j.cemconres.2006.04.002.

[24] Benyahia, A. - Choucha, S. - Ghrici, M. (2018): Influence of limestone dust and natural pozzolan on engineering properties of self-compacting repair mortars. Frattura ed Integrità Strutturale, 45:135-146, 2018. https://doi.org/10.3221/IGF-ESIS.45.11.

[25] Türkel, S. - Altuntaş Y. (2009): The effect of limestone powder, fly ash and silica fume on the properties of self-compacting repair mortars. Sādhanā, 34(2):331-343, 2009. https://doi.org/10.1007/s12046-009-0011-3.

[26] Safiuddin, M. (2008): Development of self-consolidating high performance concrete incorporating rice husk ash. Ph.D. thesis, Ontario University, Canada, 2008.

[27] Jin, I. - Domone, P. (2002): Relationships between the fresh properties of SCC and its mortar component. In: Shah SP, Daczko JA, Lingscheit JN, editors. Proceedings of the first North American conference on the design and use of self-consolidating concrete, Chicago, USA, 2002.

[28] Rizal, S. (2006): High Performance Mortars and Concretes Using Secondary Raw Materials. Freiberg University, Germany, 2006

[29] EFNARC. (2002): Specification and Guidelines for Self-compacting Concrete. Norfolk, UK, Februry, 2002.

[30] EN 196-3. (1995): Methods of testing cement-Part 1: Determination of strength, 1995.

[31] ASTM C597. (1998): Standard Test Method for Pulse Velocity Through Concrete. Annual Book of ASTM Standards, 1998.

[32] Sahmaran, M. - Christianto, H.A. - Yaman, I.O. (2006): The effect of chemical admixtures and mineral additives on the properties of selfcompacting mortars. Cement and Concrete Composite, 28(15):432-440, 2006. https://doi.org/10.1016/j.cemconcomp.2005.12.003.

[33] Kavitha, O.R. - Shanthi, V.M. - Arulraj, G.P. - Sivakumar, V.R. (2016): Microstructural studies on eco-friendly and durable Self-compacting concrete blended with metakaolin. Applied Clay Science, 124-125: 143149, 2016. https://doi.org/10.1016/j.clay.2016.02.011

\section{$\underline{\text { Ref.: }}$}

Boukhelkhal, Aboubakeur - Benabed, Benchaa: Fresh and hardened properties of self-compacting repair mortar made with a new reduced carbon blended cement

Építőanyag - Journal of Silicate Based and Composite Materials, Vol. 71, No. 4 (2019), 108-113. p. https://doi.org/10.14382/epitoanyag-jsbcm.2019.19 